
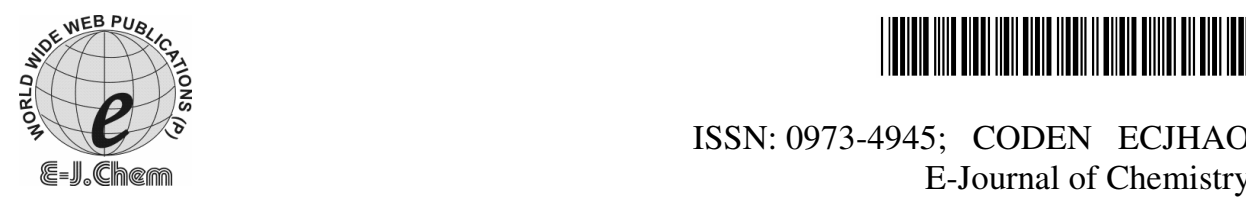

ISSN: 0973-4945; CODEN ECJHAO

\title{
Selective Removal of Toxic Metals like Copper and Arsenic from Drinking Water Using Phenol- Formaldehyde Type Chelating Resins
}

\author{
DEBASIS MOHANTY* and SHASHADHAR SAMAL \\ *Dhenkanal College, Dhenkanal, Orissa, India. \\ S.B. Rath Womens College, Berhampur, India. \\ maildebasismohanty@gmail.com
}

Received 4 January 2009; Accepted 15 March 2009

\begin{abstract}
The concentration of different toxic metals has increased beyond environmentally and ecologically permissible levels due to the increase in industrial activity. More than 100 million people of Bangladesh and West Bengal in India are affected by drinking ground water contaminated with arsenic and some parts of India is also affected by poisoning effect of copper, cadmium and fluoride. Different methods have been evolved to reduce the arsenic concentration in drinking water to a maximum permissible level of $10 \mu \mathrm{g} / \mathrm{L}$ where as various methods are also available to separate copper from drinking water. Of the proven methods available today, removal of arsenic by polymeric ion exchangers has been most effective. While chelating ion exchange resins having specific chelating groups attached to a polymer have found extensive use in sorption and pre concentration of $\mathrm{Cu}^{2+}$ ions. Both the methods are coupled here to separate and preconcentrate toxic metal cation $\mathrm{Cu}^{2+}$ and metal anion arsenate $\left(\mathrm{AsO}_{4}^{-}\right)$at the same time. We have prepared a series of low-cost polymeric resins, which are very efficient in removing copper ion from drinking water and after coordinating with copper ion they act as polymeric ligand exchanger, which are efficiently removing arsenate from drinking water. For this purpose Schiff bases were prepared by condensing $o$-phenylenediamine with $o-, m-$, and $p$-hydroxybenzaldehydes. Condensing these phenolic Schiff bases with formaldehyde afforded the chelating resins in high yields. These resins are loaded with $\mathrm{Cu}^{2+}, \mathrm{Ni}^{2+}$, and $\mathrm{Fe}^{3+}$ ions. The resins and the polychelates are highly insoluble in water. In powdered form the metal ion-loaded resins are found to very efficiently remove arsenate ion from water at neutral $\mathrm{pH}$. Resins loaded with optimum amount of $\mathrm{Cu}^{2+}$ ion is more effective in removing arsenate ions compared to those with $\mathrm{Fe}^{3+}$ ion, apparently because $\mathrm{Cu}^{2+}$ is a stronger Lewis acid than $\mathrm{Fe}^{3+}$. Various parameters influencing the removal of the arsenate ion from drinking water to a concentration level below $20 \mu \mathrm{g} / \mathrm{L}$ are studied.
\end{abstract}

Keywords: Chelating resins, Metal ion uptake, Elution, Arsenate separation. 


\section{Introduction}

The concentration of toxic metal ions like $\mathrm{Cu}(\mathrm{II}), \mathrm{Cd}(\mathrm{II}), \mathrm{As}(\mathrm{III}), \mathrm{As}(\mathrm{V}), \mathrm{Pb}(\mathrm{II}), \mathrm{Ni}(\mathrm{II})$ and $\mathrm{U}(\mathrm{VI})$ etc. has increased beyond environmentally and ecologically sustainable levels due to natural phenomenon as well as anthropogenic impact. It has resulted in severe contamination of ground and surface water. The poisoning effect of toxic metals from contaminated drinking water has evolved as one of the major health hazards in the $21^{\text {st }}$ century ${ }^{1,2}$. The adverse health effects caused by copper, mercury and arsenic poisoning are far more catastrophic than any other natural calamity through out the world in recent times. Especially in the developing countries, water and soil degradation generated by industrial effluents has been a serious issue $^{3}$. An estimated 120 million people are at risk of poisoning effect of arsenic in Bengal Delta (parts of Bangladesh, Nepal, and West Bengal), Taiwan, the USA, Chile, and Argentina. Many people are also suffering from different health hazards due to poisoning effect of copper, lead, and mercury ${ }^{4}$. Extraction of these metal ions is a tedious process as they are associated with a variety of complex species present in the natural aquatic systems. Again copper, lead, nickel, cadmium and uranium are present as cations such as $\mathrm{Cu}^{2+}, \mathrm{Pb}^{2+}, \mathrm{Cd}^{2+}$ and $\mathrm{UO}^{2+}$ in ground and surface water while arsenic is present as anions like $\mathrm{AsO}_{4}{ }^{-}$and $\mathrm{AsO}_{3}{ }^{-}$. Therefore different methods and mechanism are required to separate them from water.

Chelating ion exchange resins having specific chelating groups attached to a polymer have found extensive use in sorption and pre concentration of metal cations ${ }^{5-8}$. The Schiff bases having multiple coordination sites are known to form complexes with transition metal ion readily ${ }^{9-11}$ present in a polymeric matrix they are expected to show affinity selectivity towards the metal ions at an appropriate $\mathrm{pH}$. We have reported the synthesis, characterization and capacity studies of a number of phenol-formaldehyde type resins containing different Schiff base moiety ${ }^{12-16}$. These resins were found to react readily with several metal cations ${ }^{17,18}$. It is also a challenge to evolve a cost effective arsenic removal technology which could reduce arsenic concentration below $10 \mu \mathrm{g} / \mathrm{L}$ from ground water. In this respect a lot of research has been carried out and technologies developed. Many technologies have been evolved for arsenic removal from ground water. Of the proven methods available today, polymeric ligand exchanger (PLE) is best and most innovative available technology (BAT) for removal of As(V).

In this paper, we have tried to combined both the above idea to separate and preconcentrate toxic metal cation $\mathrm{Cu}^{2+}$ and metal anion arsenate $\left(\mathrm{AsO}_{4}^{-}\right)$at the same time. Because the ground water in some part of India contaminated with both copper and $\operatorname{arsenic}^{19}$. Here, we are report the synthesis of three phenol-formaldehyde type resins containing $o$-phenylenediamine functionalities and their metal ion uptake capacity towards metal ion such as $\mathrm{Cu}^{2+}, \mathrm{Ni}^{2+}$ and $\mathrm{Fe}^{3+}$. Copper and iron polychelate of the resins are used as polymeric ligand exchanger to remove arsenate from drinking water. A comparative study was done between the copper and iron PLE.

\section{Experimental}

The starting materials such as $o-, m-, p$ - hydroxybenzaldehyde $(o-, m-, p-\mathrm{HB})$, $o$-phenylenediamine (o-PD) (Aldrich, U.S.A) were further purified by distillation or recrystallization from ethanol. The sulfate and/or nitrate salts of $\mathrm{Cu}^{2+}, \mathrm{Ni}^{2+}$, and $\mathrm{Fe}^{3+}$, potassium dihydrogen arsenate $\left(\mathrm{KH}_{2} \mathrm{AsO}_{4}\right)$, formaldehyde and all other chemicals and solvents were of AnalaR/GR grade (Merck/BDH, India) and used as received. The buffer used to control the $\mathrm{pH}$ of the solution was acetic acid - sodium acetate ( $\mathrm{pH} 3.42$ - 6.5), ammonium hydroxide - ammonium chloride ( $\mathrm{pH} 7.8$ - 10). 


\section{Synthesis of Schiff base, resin and polychelates of resin}

The Schiff base monomers $o$-, $m$-, $p$ - hydroxybenzaldehyde- ethylenediamine $(o-, m-, p$-HB$o$-PD) were synthesized by reacting $0.01 \mathrm{~mol}$ of $o$-phenylenediamine (o-PD) with $0.02 \mathrm{~mol}$ of $o-, m-, p$ - hydroxybenzaldehyde dissolved in $20 \mathrm{~mL}$ of ethanol in presence of $0.5 \mathrm{~g}$ of anhydrous sodium acetate. The mixture was refluxed for $1 \mathrm{~h}$ at $60{ }^{\circ} \mathrm{C}$. The Schiff base $o$-HB$o$-PD was formed within 10 minutes of reaction. The formation of $m$ - and $p$-HB- $o$-PD required refluxing the mixture for $1 \mathrm{~h}$. The contents were poured into ice cold water, allowed to stand for one hour, filtered and dried at $70{ }^{\circ} \mathrm{C}$. The color of the isolated Schiff bases $o-, m$ , $p$-HB-o-PD were yellow, metallic grey and yellowish brown respectively (Figure 1). They were thoroughly washed in water, ethanol and air-dried. In the further steps, the Schiff bases were condensed separately with formaldehyde ( $\mathrm{HCHO}$ ) solutions in 1:2 molar ratios in ethanolic medium using few drops of $0.01 \mathrm{M} \mathrm{NaOH}$ solutions as catalyst and the mixture was refluxed in oil bath at $120-130{ }^{\circ} \mathrm{C}$ for $2 \mathrm{~h}$ (Figure 2). The insoluble resin was filtered, washed repeatedly with distilled water and dried at $70{ }^{\circ} \mathrm{C}$. To prepare the polychelates, to $100 \mathrm{mg}$ of the dry resin (100 mesh, ASTM) suspended over methanol, $10 \mathrm{~mL}$ of metal salt $(0.15 \mathrm{M})$ in water was added. The mixture was stirred for $2 \mathrm{~h}$ at $40{ }^{\circ} \mathrm{C}$. It was filtered, washed in distilled water followed by petroleum ether and dried at $70{ }^{\circ} \mathrm{C}$.
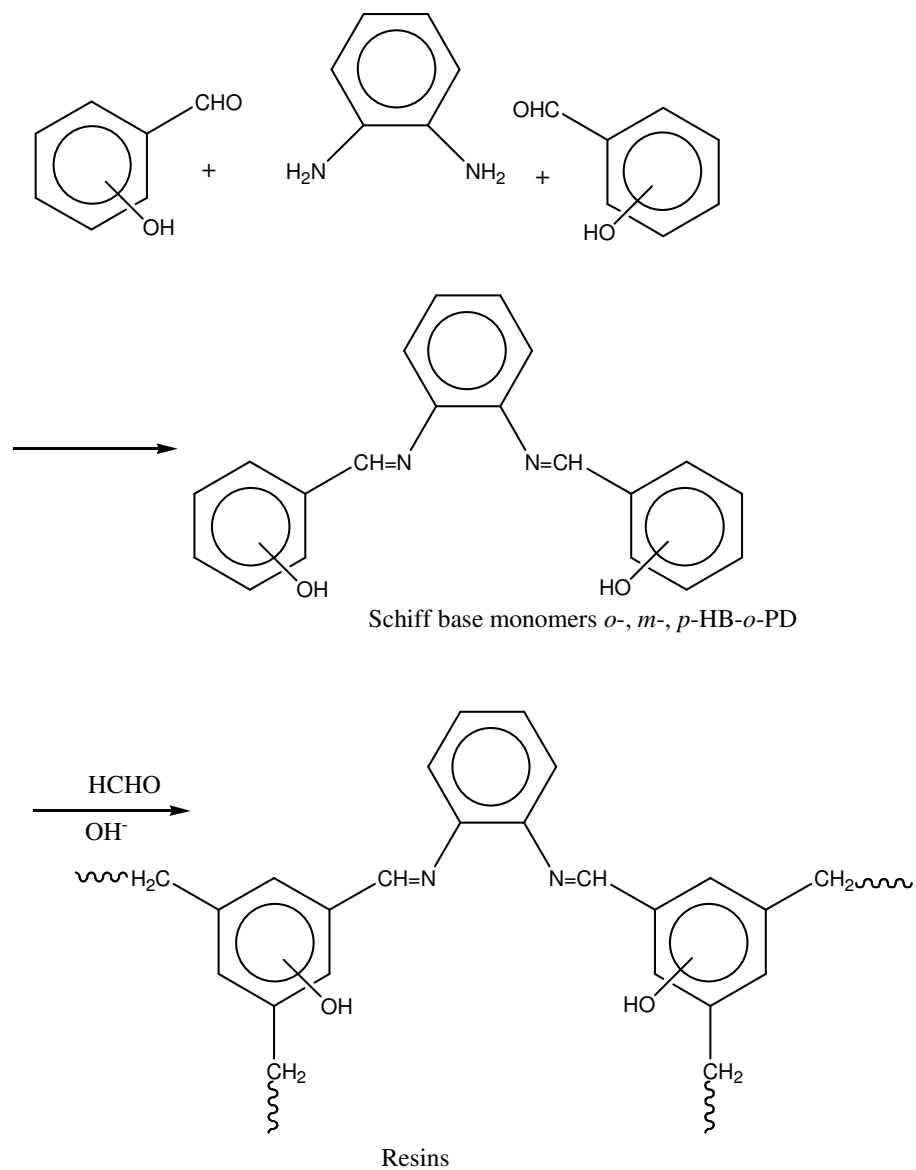

Figure 1. Schematic representation of synthesis of resin. 


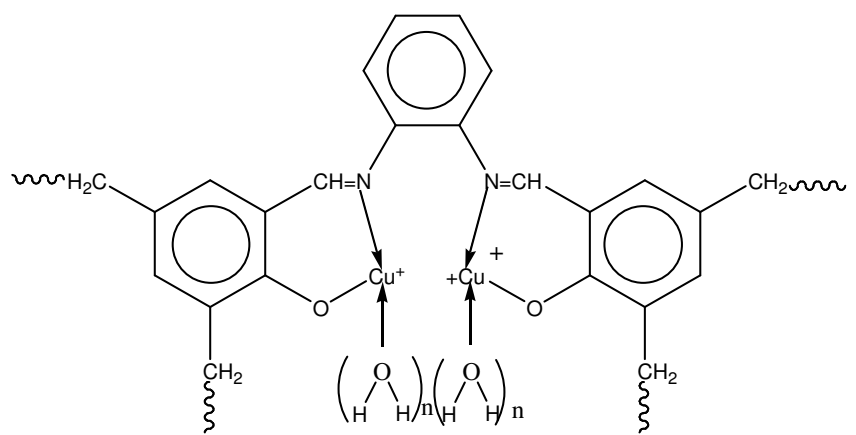

Figure 2 Structure of polychelate.

\section{Procedure for metal ion uptake experiments}

The metal ions uptake studies were done employing batch techniques. In the batch technique, a suspension of the resin in the metal solution of known volume and concentration was taken in stopper glass bottles $(100 \mathrm{~mL})$ and shaken for a definite time period at the shaking rate of 200 $\mathrm{rpm}$. The $\mathrm{pH}$ of the solution was adjusted using suitable buffer. The resin was filtered off, and thoroughly washed with demineralized water. The metal ion concentration in the filtrate and washing were estimated colorimetrically using neocuprion method for $\mathrm{Cu}(\mathrm{II})$, thiocyanate method for $\mathrm{Fe}(\mathrm{III})$ and dimethylglyoxime method for $\mathrm{Ni}(\mathrm{II})$ after proper dilution, if necessary ${ }^{20}$.

\section{Desorption and reuse}

Desorption of the metal ion was also carried out from the resin column. After loading the metal ion solutions onto the resin column at appropriate $\mathrm{pH}$, the selected eluting agent was run through the column by regulating the flow with the stopcock of the column. The desorption ratio (\%) was calculated using the following expression.

$$
\text { Desorption ratio }(\%)=\frac{\text { Quantity of metal ions desorbed to the eluting medium }}{\text { Quantity of metal ions adsorbed onto the sorbent }} \times 100
$$

The adsorption-desorption cycle was repeated at least three times with the same resin to obtain a reliable result

\section{Arsenate adsorption studies}

To $10 \mathrm{~mL}$ of the arsenate solution $\left(\left[\mathrm{AsO}_{4}{ }^{3-}\right]=200 \mu \mathrm{g} / \mathrm{L}\right), 100 \mathrm{mg}$ of the copper polychelate of 100 mesh was added and shaken for a fixed time period in stoppered conical flasks at $30^{\circ} \mathrm{C}$. The contents of the flask were filtered off and the resin was thoroughly washed in demineralized water. The metal ion concentration in the filtrate and the washings was determined by a two-channel atomic absorption/flame emission spectrophotometer. To determine the optimum conditions for efficient uptake of arsenate ions by the copper polychelate, various parameters like contact time and $\mathrm{pH}$ were varied. Doubly deionized water was used through all the experiments.

\section{Results and Discussion}

Metal ion uptake studies

Effect of contact time

The $\mathrm{Cu}(\mathrm{II}), \mathrm{Ni}(\mathrm{II})$ and $\mathrm{Fe}(\mathrm{III})$ solution were treated with the resin at natural $\mathrm{pH}$ of the solutions. The contact time was varied between $5 \mathrm{~min}$ to $24 \mathrm{~h}$. The saturation time was obtained by plotting the percentage of metal ion against the contact time variation, keeping the initial metal ion concentration fixed $(200 \mu \mathrm{g} . / 10 \mathrm{~mL}$.). In all the three resins, the rate of $\mathrm{Cu}$ (II) 
adsorption is higher than that of $\mathrm{Ni}(\mathrm{II})$ and $\mathrm{Fe}(\mathrm{III})$ (Table 1). Several authors have noted the higher adsorption of $\mathrm{Cu}(\mathrm{II})$ over other metal ions ${ }^{21,22}$ It is also found that $o$-HB-o-PD-HCHO is the most efficient resin for all the metal ions. It takes $80,49.9,48.8 \%$ of $\mathrm{Cu}(\mathrm{II}), \mathrm{NI}(\mathrm{II}), \mathrm{Fe}$ (III) respectively at $24 \mathrm{~h}$ in natural $\mathrm{pH}$ of the solution. The order of adsorption efficiency of the resin is $o$-HB- $o$-PD-HCHO $>m$-HB- $o$-PD-HCHO $>p$-HB- $o$-PD-HCHO. It could be explained on the basis that due to structural features of the above resins, the azomethine nitrogen and/or phenolic oxygen forms stable complexes on the above order. Because as we move from ortho to para complex the distance between azomethine nitrogen and phenolic oxygen increases.

Table 1. Effect of contact time.

Metal ion concentration $[\mathrm{M}]=200 \mu \mathrm{g} / 10 \mathrm{~mL}$, Resin quantity=100 mg, Resin size=100 mesh, tempt $=30{ }^{\circ} \mathrm{C}, \mathrm{pH}=5.7$

\begin{tabular}{cccccccc}
\hline \multirow{2}{*}{ Resin } & \multicolumn{7}{c}{ \% metal ion adsorbed at different time intervals } \\
& Metal ions & 0.1667 & 0.5 & 1 & 2 & 4 & 24 \\
\hline \multirow{3}{*}{$o$-HB-o-PD-HCHO } & $\mathrm{Cu}^{2+}$ & 71.5 & 76 & 76.5 & 76.8 & 77.2 & 80 \\
& $\mathrm{Ni}^{2+}$ & 6 & 11.2 & 18.5 & 35 & 46.4 & 49.9 \\
& $\mathrm{Fe}^{3+}$ & 0 & 9.7 & 10 & 33 & 46.5 & 48.8 \\
\hline \multirow{3}{*}{$m$-HB-o-PD-HCHO } & $\mathrm{Cu}^{2+}$ & 58 & 65.5 & 66.4 & 67 & 68.2 & 70 \\
& $\mathrm{Ni}^{2+}$ & 2 & 15 & 17.5 & 25.4 & 36.8 & 44 \\
& $\mathrm{Fe}^{3+}$ & 0 & 5 & 16.4 & 24 & 34.5 & 40.5 \\
\hline \multirow{3}{*}{$p$-HB- $o$-PD -HCHO } & $\mathrm{Cu}^{2+}$ & 47 & 53.8 & 54 & 55.6 & 58 & 59 \\
& $\mathrm{Ni}^{2+}$ & 0 & 6.8 & 18.5 & 20.9 & 29.7 & 31 \\
& $\mathrm{Fe}^{3+}$ & 0 & 3.5 & 10.5 & 18.7 & 26.3 & 28.9 \\
\hline
\end{tabular}

\section{Effect of $p H$}

The effect of the reaction medium on the extent of adsorption of $\mathrm{Cu}(\mathrm{II})$ and $\mathrm{Ni}(\mathrm{II})$ was studied using buffers in the $\mathrm{pH}$ range of 3.42-5.89 for $\mathrm{Cu}^{2+}, 3.42-8.9$ for $\mathrm{Ni}$ (II) and 3.42- 9.0 for $\mathrm{Fe}(\mathrm{III})$ (Figure 3a-c).The metal ions are precipitated as hydroxides beyond the above $\mathrm{pH}$ ranges. The ease of coordination of the phenoxide ion over that of phenolic $\mathrm{OH}$ group and the enhanced basicity of the $\mathrm{C}=\mathrm{N}$ nitrogen at higher $\mathrm{pH}$ are some factors for the resins to uptake high percentage of metal ions at higher $\mathrm{pH}$. Because in lower $\mathrm{pH}$, the coordinating groups get protonated ${ }^{23}$. Dev and Rao have reported enhanced adsorption of metal ions with increase $^{24}$ in the $\mathrm{pH}$. In our case, the optimum $\mathrm{pH}$ of the adsorption of $\mathrm{Cu}(\mathrm{II}), \mathrm{Ni}(\mathrm{II})$ and $\mathrm{Fe}(\mathrm{III})$ ions were $5.89,8.9$ and 9.0 respectively $^{24,25}$. It is also observed that the metal ion uptake percentage was higher in case of $o$-HB-o-PD-HCHO resin than the other two resins. However, all the three resins showed higher affinity towards $\mathrm{Cu}(\mathrm{II})$ than $\mathrm{Ni}(\mathrm{II})$ and $\mathrm{Fe}(\mathrm{III})$.

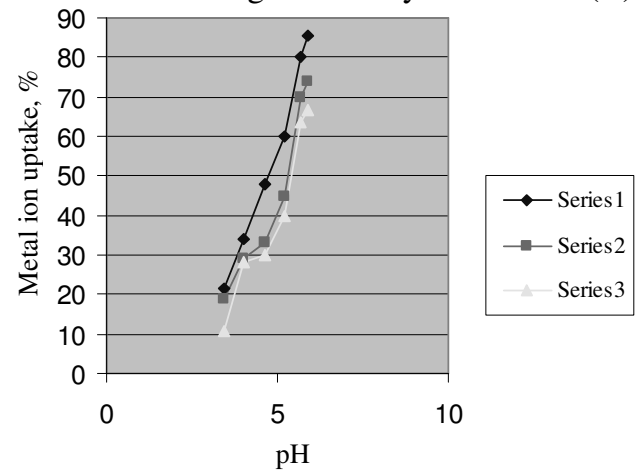

Figure 3(a). Uptake of $\mathrm{Cu}(\mathrm{II})$ ions by the resins with increasing $\mathrm{pH}$. 


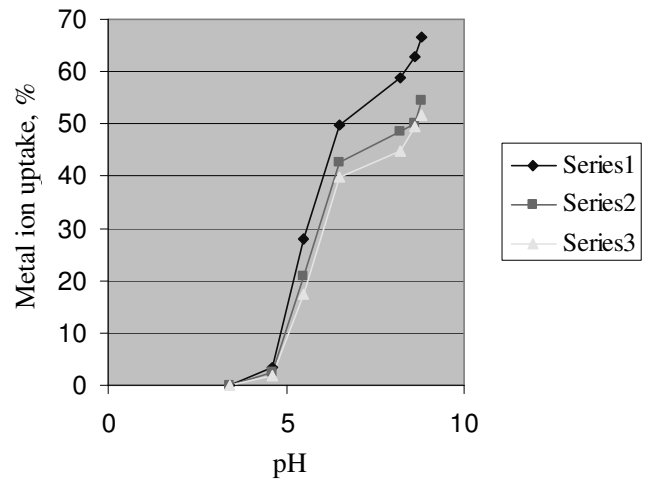

Figure 3(b). Uptake of $\mathrm{Ni}(\mathrm{II})$ ions by the resins with increasing $\mathrm{pH}$.

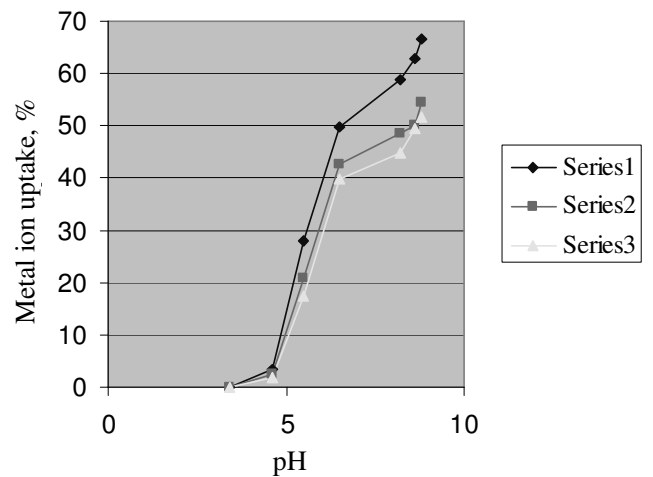

Figure 3(c). Uptake of Fe(III) ions by the resins with increasing $\mathrm{pH}$.

Series 1. For o- $\mathrm{HB}-\mathrm{o}-\mathrm{PD}-\mathrm{HCHO}$

Series 2. For m-HB-o-PD-HCHO

Series 3. For $\mathrm{p}-\mathrm{HB}$-o-PD-HCHO

\section{Effect of metal ion concentration}

The effect of metal ion concentration on the uptake behavior of the resins was studied in the metal ion concentration range $50-500 \mu \mathrm{g} / \mathrm{mL}$. It was observed that with increase in concentration of the metal ion, the amount of adsorption also increased up to a certain stage, after which there was no further increase in amount of metal ion adsorption. Many authors reported similar observations ${ }^{26}$. This could be attributed to the saturation of the available coordinating sites in the resin with the metal ion. The adsorption coefficient, $k_{\mathrm{ad}}$, of the resins for the uptake of $\mathrm{Cu}$ (II) was computed from Freundlich adsorption isotherm.

$$
\log (\mathrm{x} / \mathrm{m})=\log k_{\mathrm{ad}}+1 / \mathrm{n} \log \mathrm{C}
$$

where, ' $\mathrm{C}$ ' is the concentration of the metal ion in mmol, ' $\mathrm{m}$ ' is the weight of the resin in gram, ' $\mathrm{x}$ ' is the metal ion adsorbed by the resin in mmol and ' $\mathrm{n}$ ' is a constant. For all the resins the value of $k_{\text {ad }}$ and ' $n$ ' were found out and presented in Table 2. High $k_{\text {ad }}$ values were observed in all cases, which indicated that the equilibrium for metal ion adsorption was attained at a fast rate. Blasius and coworkers ${ }^{28}$ have reported the adsorption constant for $\mathrm{Mo}^{6+}$ and $\mathrm{W}^{6+}$ and slow adsorption rate of the metal ion was associated with low $k_{\mathrm{ad}}$ values ${ }^{27,28}$. 
Table 2. Effect of variation of metal ion concentration on adsorption behavior of resins and Freundlich adsorption isotherm data.

Metal ion: $\mathrm{Cu}(\mathrm{II})$, Resin quantity: $100 \mathrm{mg}$, Sorbent size: $100 \mathrm{mesh}$, Temperature: $30{ }^{\circ} \mathrm{C}$, Contact time: $24 \mathrm{~h}, \mathrm{pH}=5.7$

\begin{tabular}{|c|c|c|c|c|c|c|c|c|}
\hline Resin & $\begin{array}{c}{[\mathrm{Cu}(\mathrm{II})]} \\
\mu \mathrm{g} / 10 \mathrm{~mL}\end{array}$ & $\begin{array}{c}{[\mathrm{Cu}(\mathrm{II})]} \\
\mathrm{mmol}(\mathrm{C})\end{array}$ & $\log C$ & $\begin{array}{c}\mathrm{Cu}(\mathrm{II})] \\
\text { Adsorbed } \\
\mu \mathrm{g}\end{array}$ & $\begin{array}{c}{[\mathrm{Cu}(\mathrm{II})]} \\
\text { Adsorbed } \\
\text { mmol (x) }\end{array}$ & $\log x / m$ & $\mathrm{~K}_{\mathrm{ad}}$ & $1 / \mathrm{n}$ \\
\hline$o$-HB-o-PD- & 50 & 0.00008 & -4.0969 & 46 & 0.0007 & -2.1549 & 7.888 & 0.729 \\
\hline \multirow[t]{5}{*}{$\mathrm{HCHO}$} & 100 & 0.00016 & -3.7958 & 88 & 0.0014 & -1.8538 & & \\
\hline & 150 & 0.00024 & -3.6197 & 127.5 & 0.002 & -1.6989 & & \\
\hline & 200 & 0.00031 & -3.5086 & 160 & 0.0025 & -1.602 & & \\
\hline & 300 & 0.00047 & -3.3279 & 200 & 0.0031 & -1.5086 & & \\
\hline & 500 & 0.00079 & -3.1023 & 230.5 & 0.0036 & -1.4436 & & \\
\hline$m$-HB- $o$-PD & 50 & 0.00008 & -4.0969 & 43 & 0.00067 & -2.1739 & 5.662 & 0.706 \\
\hline \multirow[t]{5}{*}{-HCHO } & 100 & 0.00016 & -3.7958 & 78 & 0.0012 & -1.9208 & & \\
\hline & 150 & 0.00024 & -3.6197 & 110.5 & 0.0017 & -1.7695 & & \\
\hline & 200 & 0.00031 & -3.5086 & 125 & 0.0019 & -1.7077 & & \\
\hline & 300 & 0.00047 & -3.3279 & 178.6 & 0.0028 & -1.5528 & & \\
\hline & 500 & 0.00079 & -3.1023 & 206.5 & 0.0032 & -1.4948 & & \\
\hline$p$-HB- $o$-PD & 50 & 0.00008 & -4.0969 & 41.5 & 0.00065 & -2.187 & 2.6 & $\overline{0.6}$ \\
\hline \multirow[t]{5}{*}{-HCHO } & 100 & 0.00016 & -3.7958 & 74.5 & 0.00117 & -1.9318 & 91 & 26 \\
\hline & 150 & 0.00024 & -3.6197 & 116.9 & 0.00184 & -1.7351 & & \\
\hline & 200 & 0.00031 & -3.5086 & 107.5 & 0.00169 & -1.7721 & & \\
\hline & 300 & 0.00047 & -3.3279 & 135.6 & 0.00213 & -1.6716 & & \\
\hline & 500 & 0.00079 & -3.1023 & 181.8 & 0.00286 & -1.5436 & & \\
\hline
\end{tabular}

Effect of added salt

Effect of the cations like $\mathrm{Na}^{+}, \mathrm{K}^{+}$and $\mathrm{Mg}^{2+}$ on the adsorption behavior of the resin towards $\mathrm{Cu}$ (II) was observed. It is done by treating $100 \mathrm{mg}$ of all the resins with $200 \mu \mathrm{g}$ per $10 \mathrm{~mL}$ of the $\mathrm{Cu}$ (II) in presence of the above alkali and alkaline earth metal ion solution at the natural $\mathrm{pH}$ of the solution for $24 \mathrm{~h}$. It was observed that the presence of alkali and alkaline earth metal ions and the accompanying anion have negligible effect on the adsorption behavior of the resins (Table 3 ). Hence, the resin could be used to remove $\mathrm{Cu}$ (II) ion from saline and non-saline water rich in these above cations. Hodgkin and $\mathrm{Eibl}^{29}$ prepared a $\mathrm{Cu}^{2+}$ - selective (sirorez - $\mathrm{Cu}$ ) from phenolformaldehyde and piparazine and the selective capacity for $\mathrm{Cu}^{2+}$ was studied in the $\mathrm{pH}$ range 3-10.5. They observed that, the alkali and alkaline earth metals were not retained by the resin in this range. Dev and $\mathrm{RaO}^{24}$ also reported the same observation as we are report in this paper.

Table 3. Effect of added salt on the adsorption of $\mathrm{Cu}(\mathrm{II})$ ion by the resin.

Metal ion: $\mathrm{Cu}(\mathrm{II}),[\mathrm{Cu}(\mathrm{II})]: 200 \mu \mathrm{g} / 10 \mathrm{~mL}$, Resin quantity: $100 \mathrm{mg}$, Sorbent size: $100 \mathrm{mesh}$, Temperature: $30{ }^{\circ} \mathrm{C}, \mathrm{pH}: 5.7$, Contact time: $24 \mathrm{~h}$.

\begin{tabular}{ccccc}
\hline \multirow{2}{*}{ Resin } & \multicolumn{4}{c}{$\mathrm{Cu}(\mathrm{II})$ uptake } \\
\cline { 2 - 5 } & $\begin{array}{c}\text { In absence of } \\
\text { added salt }\end{array}$ & \multicolumn{3}{c}{ In presence of added salt } \\
\cline { 2 - 5 } $\mathrm{Na}^{+}$ & 79.8 & 79.5 & $\mathrm{Kg}^{+}$ \\
\hline$o$-HB- $o$-PD-HCHO & 80 & 69.6 & 69.6 & 69.2 \\
$m$-HB- $o$-PD -HCHO & 70 & 58.6 & 58.5 & 58.3 \\
$p$-HB- $o$-PD -HCHO & 59 & &
\end{tabular}




\section{Separation}

To know the adsorption efficiency of the resins in a competitive environment where both $\mathrm{Cu}(\mathrm{II})$ and $\mathrm{Fe}$ (III) ions are present, two set of experiments were carried out. In the first set of experiment $10 \mathrm{~mL}$ of solution containing $200 \mu \mathrm{g}$ each of $\mathrm{Cu}(\mathrm{II})$ and $\mathrm{Fe}(\mathrm{III})$ was treated with $100 \mathrm{mg}$ of the resins at varying $\mathrm{pH}$ (Table 4). It was found that in the $\mathrm{pH}$ range 3.42-4.63 all the resins exclusively adsorbs $\mathrm{Cu}^{2+}$ ion while in the $\mathrm{pH}$ range 4.63-5.89 all the resins adsorbs high percentage of $\mathrm{Cu}^{2+}$ with many fold increase in the $\mathrm{k}_{\mathrm{d}}$ value along with a small amount of $\mathrm{Fe}^{3+}$ and most efficient among all the resin is $o-\mathrm{HB}-o-\mathrm{PD}-\mathrm{HCHO}$. Mendez and Pillai ${ }^{30}$ have reported a resin which is highly selective for $\mathrm{Cu}^{2+}$ over $\mathrm{UO}_{2}{ }^{2+}$ and $\mathrm{VO}^{2+}$ above $\mathrm{pH} 3$.

Table 4. Separation of $\mathrm{Cu}$ (II) from a mixture of $\mathrm{Cu}(\mathrm{II})$ and $\mathrm{Fe}(\mathrm{III})$ at varying $\mathrm{pH}$.

Metal ion: [Cu(II)]=[Fe(III)]: $200 \mu \mathrm{g} / 10 \mathrm{~mL}$, Resin quantity: $100 \mathrm{mg}$, Sorbent size: $100 \mathrm{mesh}$, Temperature: $30{ }^{\circ} \mathrm{C}$, Contact time: $24 \mathrm{~h}, \mathrm{pH}: 5.7$.

\begin{tabular}{cccccc}
\hline \multirow{2}{*}{ Resin } & \multirow{2}{*}{$\mathrm{pH}$} & \multicolumn{2}{c}{$\mathrm{Cu}(\mathrm{II})$} & \multicolumn{2}{c}{$\mathrm{Fe}(\mathrm{III})$} \\
\cline { 3 - 6 } & 3.42 & Uptake, $\%$ & $\mathrm{~K}_{\mathrm{d}}$ & Uptake, $\%$ & $\mathrm{~K}_{\mathrm{d}}$ \\
\hline \multirow{5}{*}{$o$-HB-o-PD-HCHO } & 4.0 & 33.5 & 17.64 & 0 & 0 \\
& 4.63 & 42.5 & 73.91 & 0 & 0 \\
& 5.2 & 57.5 & 135.29 & 0 & 0 \\
& 5.5 & 71.7 & 215.31 & 15 & 14.28 \\
& 5.89 & 83.4 & 502.4 & 20.0 & 25.0 \\
\hline & 3.42 & 15.5 & 18.34 & 0 & 0 \\
$m$-HB-o-PD-HCHO & 4.0 & 27 & 36.98 & 0 & 0 \\
& 4.63 & 31.7 & 46.41 & 0 & 0 \\
& 5.2 & 35.9 & 56.0 & 9.7 & 10.74 \\
& 5.5 & 65.3 & 188.18 & 13.2 & 15.20 \\
& 5.89 & 69.7 & 230.03 & 18.5 & 22.64 \\
\hline \multirow{5}{*}{$p$-HB- $o$-PD-HCHO } & 3.42 & 9.7 & 10.74 & 0 & 0 \\
& 4.0 & 23.7 & 31.06 & 0 & 0 \\
& 4.63 & 25.5 & 34.22 & 0 & 0 \\
& 5.2 & 33.5 & 50.37 & 0 & 0 \\
& 5.5 & 55.8 & 126.24 & 10.2 & 11.35 \\
& 5.89 & 62.8 & 168.81 & 12.5 & 14.28 \\
\hline
\end{tabular}

In the second set of experiment, $10 \mathrm{~mL}$ of the solution containing a fixed amount of $\mathrm{Cu}^{2+}(200 \mu \mathrm{g} / 10 \mathrm{~mL})$ and varying amounts of $\mathrm{Fe}^{3+}(100-400 \mu \mathrm{g} / 10 \mathrm{~mL})$ was treated with $100 \mathrm{mg}$ of the resins at affixed $\mathrm{pH}$ for $24 \mathrm{~h}$ (Table 5). It was seen that at $\mathrm{pH} 5.89$, all resins take up $\mathrm{Cu}^{2+}$ quantitatively and the adsorption of $\mathrm{Fe}^{3+}$ was negligible. Again the most efficient resin is $o$-HB-o-PD-HCHO. Therefore it can be concluded that in a competitive environment where both $\mathrm{Cu}$ (II) and $\mathrm{Fe}$ (III) are present these resins are quantitatively adsorbs $\mathrm{Cu}(\mathrm{II})$ over $\mathrm{Fe}(\mathrm{III})$ and forms effective metal complex with $\mathrm{Cu}(\mathrm{II})$ ions.

\section{Arsenate adsorption studies}

Literature survey shows that most of the work on metal-loaded polymers used for separation of arsenate has been done with $\mathrm{Fe}(\mathrm{III})$, but these sorbents cannot be effectively used for drinking water treatment ${ }^{31-33}$. Because all observation shows that only at low $\mathrm{pH} \mathrm{As}(\mathrm{V}) \mathrm{can}$ be removed. Again, because of the weak Lewis acid characteristic of ferric ions, the amount of $\mathrm{Fe}^{3+}$ loaded was low. Moreover, the loaded iron was nearly completely stripped off the hosting resin during regeneration and reloading of $\mathrm{Fe}^{3+}$ was necessary after each cycle of operation. Realizing the critical drawbacks of $\mathrm{Fe}^{3+}$ ions, Raman and Sengupta ${ }^{34}$ prepared a 
PLE by loading $\mathrm{Cu}^{2+}$ onto a weak base chelating resin (known as DOW 2N) with 2picolylamine groups. Since $\mathrm{Cu}^{2+}$ is a much stronger Lewis acid than $\mathrm{Fe}^{3+}$, according to the Irving and Williams ${ }^{35}$ order. So a much greater metal-loading capacity was observed. The copper loaded DOW $2 \mathrm{~N}$ showed orders of magnitude greater selectivity for arsenate and selenate in the presence of competing sulfate ions than commercial SBA resins ${ }^{36}$. Here we used the $\mathrm{Cu}(\mathrm{II})$ polychelate of the most efficient resin $o$-HB-o-PD-HCHO as polymeric ligand exchanger (PLE) and studied the arsenate adsorption capacity of it. Also compared the result with the arsenate adsorption capacity of the Fe(III) polychelate of the same resin. The metal polychelates were synthesized using the metal nitrate salts. We have also observed similar result as Raman and Sengupta ${ }^{34}$ which is discussed below.

Table 5. Separation of $\mathrm{Cu}$ (II) from a mixture of $\mathrm{Cu}$ (II) and $\mathrm{Fe}(\mathrm{III})$ with increasing $\mathrm{Fe}(\mathrm{III})$ concentration at fixed varying $\mathrm{pH}$.

Resin quantity: $100 \mathrm{mg}$, Sorbent size: 100 mesh, Temperature: $30^{\circ} \mathrm{C}$, Contact time: $24 \mathrm{~h}, \mathrm{pH}: 5.89$

\begin{tabular}{lcccc}
\hline \multirow{2}{*}{ Resin } & \multicolumn{2}{c}{$[\mathrm{M}] \mu \mathrm{g} / 10 \mathrm{~mL}$} & \multicolumn{2}{c}{ Metal ion uptake \% } \\
\cline { 2 - 5 } & $\mathrm{Cu}(\mathrm{II})$ & $\mathrm{Fe}(\mathrm{III})$ & $\mathrm{Cu}(\mathrm{II})$ & $\mathrm{Fe}(\mathrm{III})$ \\
\hline$o$-HB- $o$-PD-HCHO & 200 & 100 & 84.2 & 0 \\
& 200 & 200 & 83.4 & 20.0 \\
& 200 & 400 & 55 & 24.7 \\
\hline$m$-HB- $o$-PD -HCHO & 200 & 100 & 71.8 & 0 \\
& 200 & 200 & 69.7 & 18.5 \\
& 200 & 400 & 40 & 19.7 \\
\hline$p$-HB- $o$-PD -HCHO & 200 & 100 & 64.6 & 0 \\
& 200 & 200 & 62.8 & 12.5 \\
& 200 & 400 & 35.1 & 16.4 \\
\hline
\end{tabular}

\section{Equilibrium time}

To determine the equilibrium time for the adsorption of arsenate ions $100 \mathrm{mg}, 100 \mathrm{mesh}$ of the polychelates $o$-HB-o-PD-HCHO -Cu(II), $o$-HB-o-PD-HCHO -Fe(III) were treated with metal salt solutions $(2 \mu \mathrm{g} / 10 \mathrm{~mL})$ at the $7.0 \mathrm{pH}$ of the reaction mixture. The contact time was varied between $5 \mathrm{~min}$ to $24 \mathrm{~h}$. Comparing the arsenate adsorption capacity of the PLEs, it is observed that the arsenic uptake efficiency of $o-\mathrm{HB}-o-\mathrm{PD}-\mathrm{HCHO}-\mathrm{Cu}(\mathrm{II})$ polychelate is significantly higher than that of $o$-HB-o-PD-HCHO-Fe(III). The former PLE is able to take $80.2 \%$ of arsenate ion at $24 \mathrm{~h}$ in natural $\mathrm{pH}$ of the solution while the later only adsorbs $52.8 \%$ of arsenate (Table 6). The reason for such an observation could be attributed to the concurrent Lewis acidbase interactions between arsenate and the immobilized $\mathrm{Cu}^{2+}$ ions at the sorbent-sorbate interface. Under the experimental conditions, monohydrogen arsenate $\left(\mathrm{HAsO}_{4}{ }^{2-}\right)$ is considered as predominant arsenate species. $\mathrm{HAsO}_{4}{ }^{2-}$ is a divalently charged, bidentate ligand and stronger lewis base. Consequently, interactions between arsenate and the immobilized $\mathrm{Cu}^{2+}$ ions involve both $\mathrm{LAB}$ interaction (or inner-sphere complexation) and ion pairing (or electrostatic interactions) (Figure 4). It is noteworthy that LAB interaction also enhances the electrostatic interactions between arsenate and the loaded $\mathrm{Cu}^{2+}$ ions. This is because the inner-sphere complexation occurs over a much shorter distance than outer-sphere complexation, and the electrostatic interactions within the much shortened distance are much stronger in accord with the Coulomb's law. But due to weak acid strength of $\mathrm{Fe}^{3+} o$-HB-o-PD-HCHO -Fe(III) has comparatively lower arsenate adsorption capacity than $o-\mathrm{HB}-o$-PD-HCHO-Cu(II).

It was also observed that competing ions like sulphate has negligible effect on the arsenate adsorption. Though sulfate is also a divalently charged ligand, it is a much weaker Lewis base than the arsenate. Therefore interactions between sulfate and the $\mathrm{Cu}^{2+}$ ions is predominantly ion 
paring. Therefore $o$-HB-o-PD-HCHO-Cu(II) offered much greater affinity for arsenate over sulfate. Again in case of SBA resins, the commercial SBA resins ${ }^{36}$, take up anions predominately through electrostatic interactions, i.e., the ligand strength of an anion does not play a role in sorption affinity. Therefore, SBA resins are not selective for arsenate. Similar observations were reported by Zhao et al. ${ }^{36}$ by performed similar experiments over DOW 3N-Cu PLE.

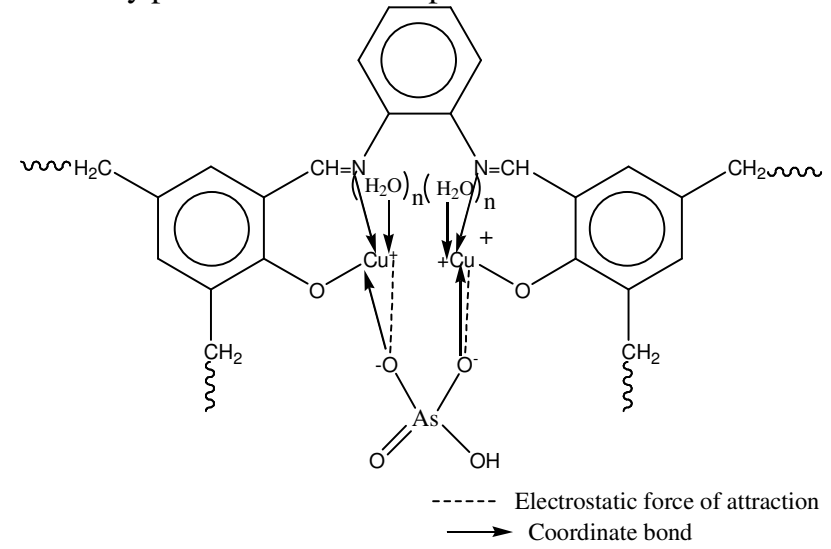

Figure 4. Structure of $o-\mathrm{HB}-o-\mathrm{PD}-\mathrm{HCHO}-\mathrm{Cu}(\mathrm{II})$.

Table 6. Effect of contact time for arsenate adsorption studies.

$\left[\mathrm{HAsO}_{4}{ }^{2-}\right]=200 \mu \mathrm{g} / \mathrm{L}$, polychelate $=100 \mathrm{mg}$, sorbent size $=100 \mathrm{mesh}$, temp $=30^{\circ} \mathrm{C}, \mathrm{pH}=7.0$.

\begin{tabular}{lcc}
\hline Contact & \multicolumn{2}{c}{$\mathrm{AsO}_{4}{ }^{3-}$ ion uptake \% } \\
\cline { 2 - 3 } Time, $\mathrm{h}$ & $o$-HB-o-PD-HCHO-Cu(II) & $o$-HB-o-PD-HCHO-Fe(III) \\
\hline 0.1667 & 0 & 0 \\
0.5 & 21.3 & 8.5 \\
1.0 & 45.5 & 17.1 \\
2.0 & 59.0 & 29.5 \\
4.0 & 72.5 & 41.7 \\
24.0 & 80.2 & 52.8 \\
\hline
\end{tabular}

\section{Effect of $p H$}

As in any ion exchange process, the PLE's selectivity for various competing ligands can be strongly influenced by solution $\mathrm{pH}$. Solution $\mathrm{pH}$ can affect the PLE's As uptake in two different aspects. First, solution $\mathrm{pH}$ governs the speciation of arsenate, resulting in arsenate species $\left(\mathrm{H}_{3} \mathrm{AsO}_{4}, \mathrm{H} 2 \mathrm{AsO} 4^{-}, \mathrm{HAsO}_{4}{ }^{2-}\right.$, and $\left.\mathrm{AsO}_{4}{ }^{3-}\right)$ of different ionic charges and ligand strength. Second, the hydroxyl anions become aggressively formidable competitors for the ligand exchange sites as solution $\mathrm{pH}$ goes up.

The effect of $\mathrm{pH}$ of the reaction medium on the extent of adsorption was studied extensively. The extent of adsorption of the PLEs was investigated using buffers in the $\mathrm{pH}$ range 3.42-8.8. It is observed that with increase in $\mathrm{pH}$ the arsenate adsorption capacity $o$ HB- $o$-PD-HCHO-Cu(II) increased till $\mathrm{pH} 7.0$ and then decreased but for $o$-HB- $o$-PD-HCHO $-\mathrm{Fe}$ (III) with increase in $\mathrm{pH}$ the arsenate adsorption capacity decreased (Table 7).

Sharp declination was observed in case of $o-\mathrm{HB}-o-\mathrm{PD}-\mathrm{HCHO}-\mathrm{Cu}$ (II) after the $\mathrm{pH}$ range 8.0. Figure $5 \mathrm{~b}$ indicates that the optimal arsenate uptake occurs in the $\mathrm{pH}$ range of 6.0-8.0, with the peak uptake being at $\mathrm{pH} 7.0$. At $\mathrm{pH} 4$ or $>10$ there was virtually no uptake of arsenate observed. It is also interesting that As uptake started increasing at $\mathrm{pH} 4.0$ almost in proportion to the increasing 
formation of the bidentate hydrogen arsenate species $\left(\mathrm{HAsO}_{4}{ }^{2}\right)$. However, the As uptake dropped sharply as $\mathrm{pH}$ exceeded 8.0. Based on both ligand strength and ionic charge, the adsorbability of various arsenate species follows the sequence $\mathrm{H}_{3} \mathrm{AsO}_{4}<\mathrm{H}_{2} \mathrm{AsO}_{4}{ }^{-}<\mathrm{HAsO}_{4}{ }^{2-}<\mathrm{AsO}_{4}{ }^{3}$. At $\mathrm{pH}<4$ the much less adsorbable $\mathrm{H}_{2} \mathrm{AsO}_{4}^{-}$or $\mathrm{H}_{3} \mathrm{AsO}_{4}$ is the predominant arsenate species, which cannot stand the competition of divalently charged sulfate anions. As a result, no As uptake is likely in the low $\mathrm{pH}$ range as observed in Figure 5(a-b). The fact that the As uptake appears to be in proportion to the formation of $\mathrm{HAsO}_{4}{ }^{2-}$ in the $\mathrm{pH}$ range of 4.0 -7.0 agrees with the notion that to overcome the competition from sulfate, arsenate must be converted to the more adsorbable $\mathrm{HAsO}_{4}{ }^{2-}$ species.

Table 7. Effect of $\mathrm{pH}$ for arsenate adsorption studies.

$\left[\mathrm{HAsO}_{4}{ }^{2-}\right]=200 \mu \mathrm{g} / \mathrm{L}$, polychelate $=100 \mathrm{mg}$, sorbent size $=100 \mathrm{mesh}$, temp $=30^{\circ} \mathrm{C}$, contact time $=24 \mathrm{~h}$.

\begin{tabular}{lcc}
\hline \multirow{2}{*}{$\mathrm{H}$} & \multicolumn{2}{c}{$\mathrm{AsO}_{4}{ }^{3-}$ ion uptake \% } \\
\cline { 2 - 3 } & $o$-HB-o-PD-HCHO-Cu(II) & $o$-HB-o-PD-HCHO-Fe(III) \\
\hline 3.42 & 0 & 67.3 \\
4.63 & 24.0 & 61.0 \\
5.5 & 63.5 & 56.3 \\
7.0 & 79.9 & 52.7 \\
7.8 & 57.8 & 45.1 \\
8.2 & 33.2 & 28.6 \\
8.8 & 8.7 & 18.9 \\
\hline
\end{tabular}

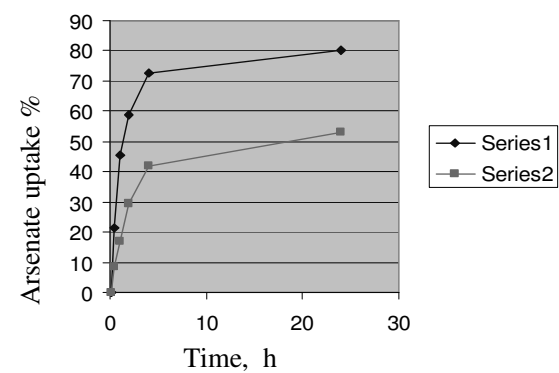

Figure-5(a). Effect of contact time on arsenate adsorption.

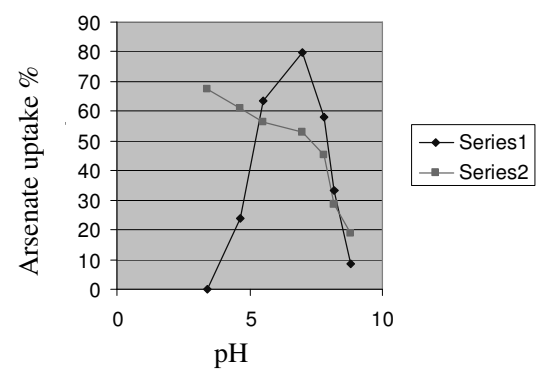

Figure- 5(b). Effect of $\mathrm{pH}$ on arsenate adsorption.

Series 1. For o- $\mathrm{HB}$-o-PD-HCHO-Cu(II)

Series 2. For o-HB-o-PD-HCHO-Fe(III)

\section{Conclusion}

It can be concluded that the phenolic Schiff base resins containing $o$-phenylenediamine are very efficient for uptake of various cations of heavy metals like copper, nickel and iron etc. Again the copper polychelates of $o$-HB-o-PD-HCHO can be used as a polymeric ligand exchanger for effective separation of arsenate from drinking water. So by the help of the resin and its polychelate simultaneously the toxic cation $\mathrm{Cu}(\mathrm{II})$ and toxic anion arsenate can be separated from drinking water. Hence the resins and polychelates of the phenolic Schiff bases are very useful in combating poisoning due to toxic metal ions, such as, copper and arsenic, etc.

\section{Acknowledgements}

The kind of help of CDRI, Lucknow, IIT Delhi, IIT Kharagpur, RRL Bhubaneswar in providing various spectra and library facilities was acknowledged. 


\section{References}

1. Bagla P and Kaiser J, Science, 1996, 274, 174.

2 Lepkowski W, Arsenic Crisis in Bangladesh, C\&EN News, 1998, 27, November 16.

3 Clayton G D and Clayton F E, Patty's Industrial Hygiene; Toxicology, WileyInterscience, New York, Vol. 2C, 1994.

4 Camuglia J E, Grigoriadis G and Gilfillan C P, Med J Aust., 2008, 189(6),339.

5 Dingman Jr J, Siggia S, Barton C and Hiscock K B, Anal Chem., 1973, 44, 1045.

6 Blount C W, Leyden D E, Thomas T L and Guill S M, Anal Chem., 1973, 44, 1045.

$7 \quad$ Moyer E M J B and Fritz J B, Anal Chem., 1977, 49, 418.

8 Bohra S, Mathur R, Mathur N K and Mathur P N, J Polym Mater., 1992, 9, 101.

$9 \quad$ Ueno K and Martell A E, J Phys Chem., 1955, 59, 998.

10 Ueno K and Martell A E, J Phys Chem., 1956, 60, 1270.

11 Che C M and Cheng W K, J Chem Soc Chem Commun., 1986, 1443.

12 Dey R K, Acharya S, Samal S and Ray A R, Ind J Chem Tech., 2004, 11, 695.

13 Samal S, Acharya S, Mohapatra P and Dey R K, Res J Chem Environ., 2000, 4(3), 11.

14 Samal S, Das R R, Dey RK and Acharya S, J Appl Polym Sci., 2000, 77, 967.

15 Samal S, Acharya S, Dey R K and Ray A R, Talanta, 2000, 57, 1075.

16 Samal S, Das R R, Acharya S, Dey R K and Mohapatra P, Polym-Plast Technol Eng., 2002, 41(2), 229.

17 Samal S, Das R R, Sahoo D and Acharya S, Polym Int., 1997, 41, 44; Samal S, Mohapatra N K, Acharya S and Dey R K, React Funct Polym., 1999, 42, 37; Samal S, Acharya S, Dey R K and Ray A R, J Appl Polym Sci., 2003, 88, 570.

18 Dey R K, Jha U, Singh A C, Samal S and Ray A R, Anal Sci., 2006, 22, 1105.

19 Acharyya S K, Lahiri S, Raymahashay B C and Bhowmik A, Environ Geol., 2000, 39(10), 1127.

20 Basset J, Denny RC, Jeffery GH, Mendham J. Vogels Text Book, ${ }^{\text {th }}$ Ed.,1978, pp.156, 747.

21 Tonisinge S, Hirai M, Ueshima H and Ueno K, Anal Chem Acta., 1979, 115, 285.

22 Suggi A, Ogawa N and Hashizume H, Talanta, 1979, 26, 189.

23 Verweij P D, Sital S, Haanepen M J, Driessen W L, Reedijik J., Eur Polym J., 1993, 29(12), 1603.

24 Dev K and Rao G N, Talanta, 1996, 43, 451.

25 Rivas B L, Maturana H A, Catalan R E and Rerich I M, J Appl Polym Sci., 1989, 38, 301.

26 Tikhomirova T I, Fadeeva V I, Kubryavtsev G V, Nesterenko P N, Ivanov V M, Savitchev A T and Smirnova N S, Talanta, 1991, 38(3), 267.

27 Blasius E and Brozio B, Z Anal Chem., 1963, 192, 364.

28 Blasius E and Brozio B, Fresenius Z Anal Chem., 1963, 192, 364.

29 Hodgkin J H and Eibl R, React polym Ion Exch sobents, 1985, 3, 83; Hodgkin J H, Chem Ind (London), 153, 1979.

$30 \quad$ Mendez R and Pillai V N S, Analyst, 1990, 115, 231.

31 Yoshida I and Ueno K, Sep Sci Technol., 1978, 13(2), 173.

32 Matsugana H, Yokoyama T, Eldridge R J and Bolto B A, React Funct Polym., 1996, 29, 167.

33 Haron M J, Yunus W M, Wan Z, Yong N L and Tokunaga S, Chemosphere., 1999, 39(14), 2459.

34 Ramana A and Sengupta A K, J Environ Eng., 1992, 118(5), 755.

35 Irving, H M N H and Williams, R J P, J Chem Soc., 1953, 3192.

36 Byungryul A, Steinwinder T R and Zhao D, Water Res., 2005, 39, 4993. 


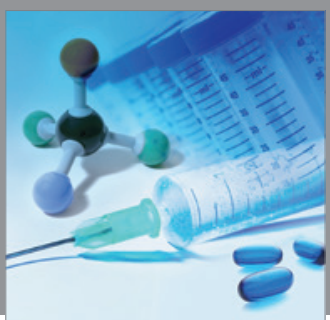

International Journal of

Medicinal Chemistry

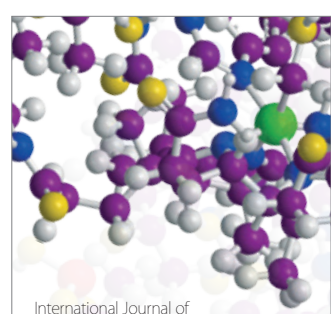

Carbohydrate Chemistry

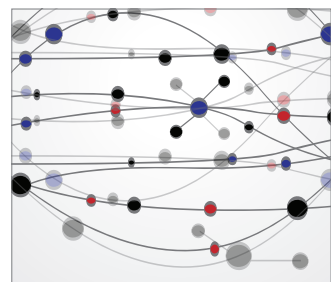

The Scientific World Journal
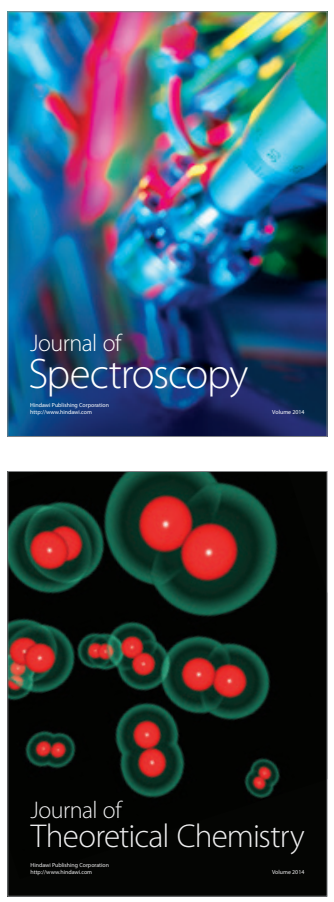
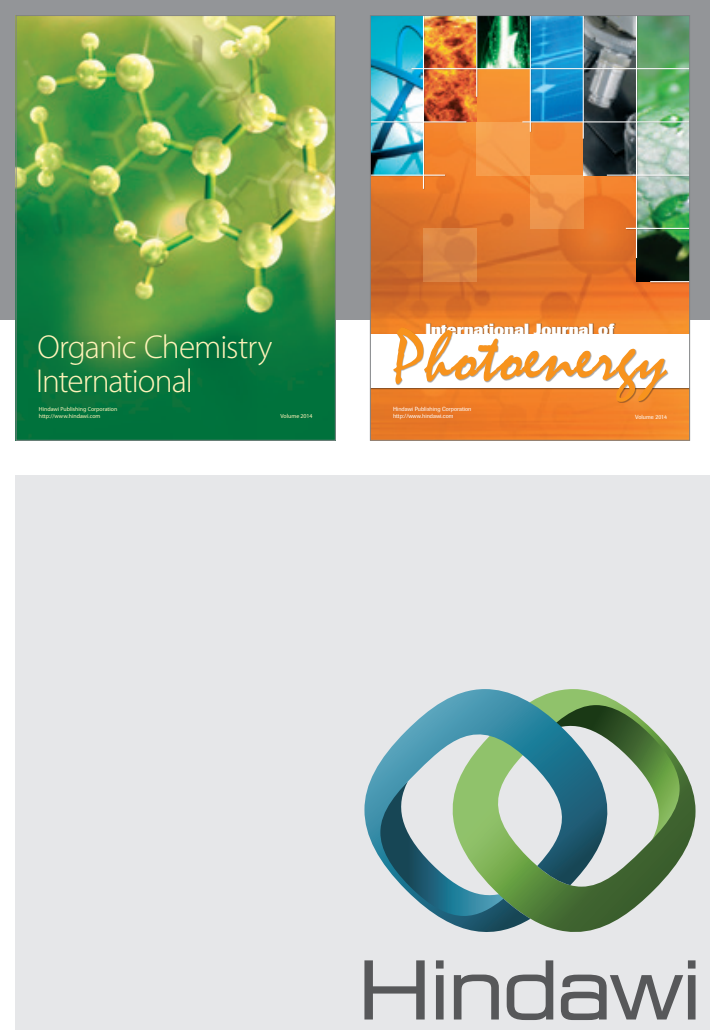

Submit your manuscripts at

http://www.hindawi.com
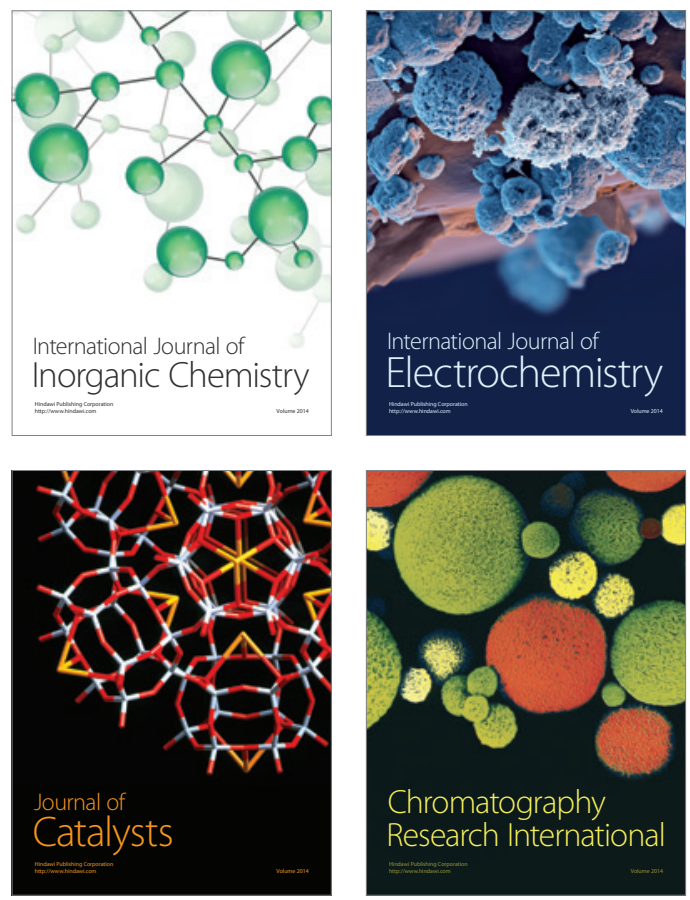
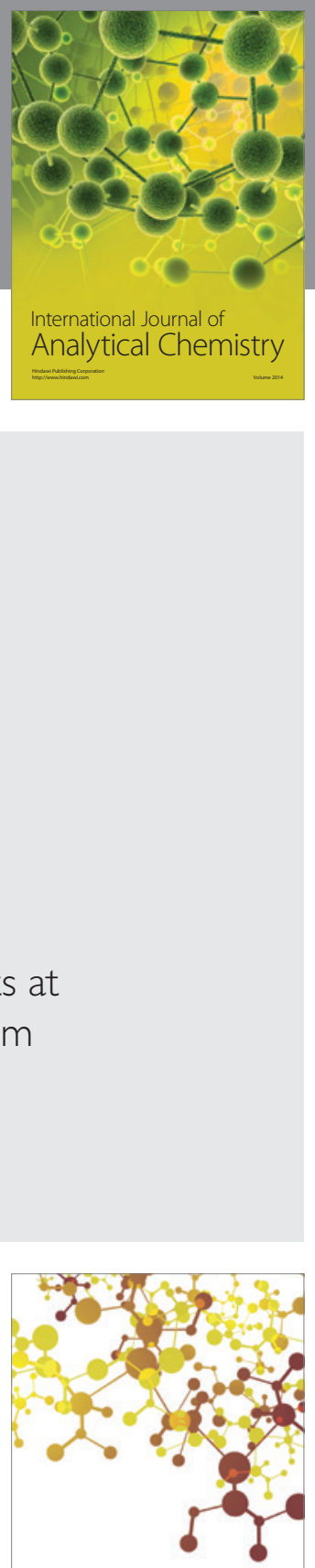

Journal of

Applied Chemistry
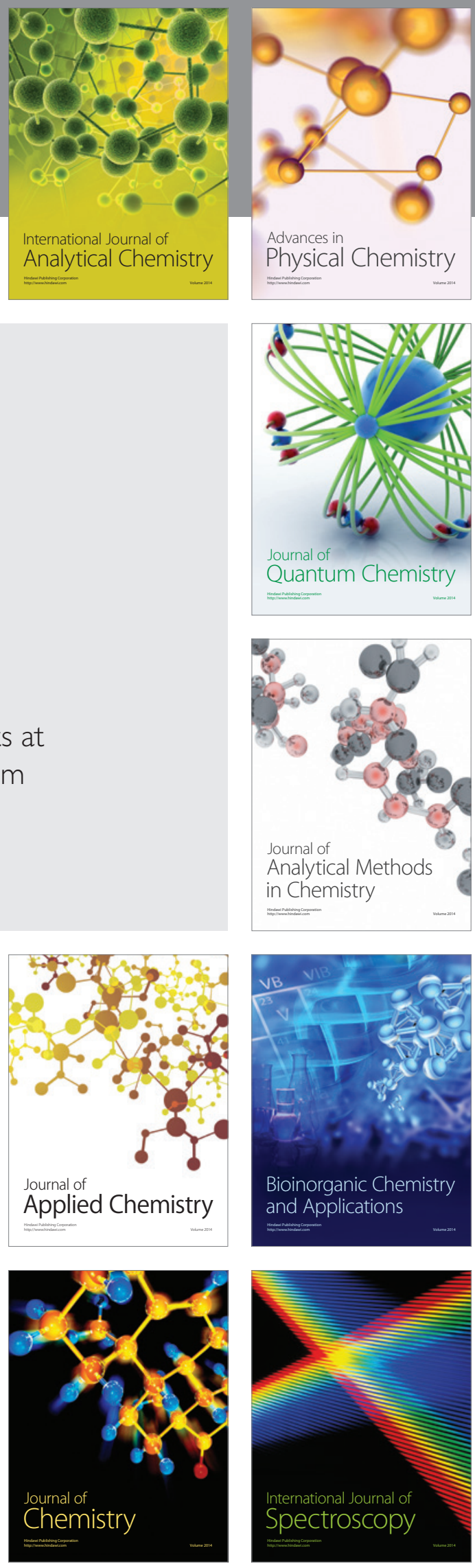